\title{
$\operatorname{arCOS} D E S I G N$
}

\section{GreenUP HUB: projetando e construindo infraestruturas verdes Funcionais no Brasil}

Giacomo Pirazzoli (FAU-Mackenzie and School of Architecture-Università di Firenze)

crossing@GPspace.org

GreenUP HUB -

Universidade Presbiteriana Mackenzie,

Faculdade de Arquitetura e Urbanismo

Rua da Consolação 896 - Prédio 9, Consolação - São Paulo, Brasil

School of Architecture-Università di Firenze

Via della Mattonaia 14 - 50121 Firenze (Itália) 


\title{
GreenUP HUB: projetando e construindo infrastructuras verdes funcionais no Brasil
}

\section{Resumo:}

Objetivo: Embora de modo breve, o texto visa revisar cronologicamente a pesquisa de 5 anos da GreenUP voltando a se concentrar em seu lado teórico relacionado com o aprendizado - depois, além da prática real. Métodos: bottom-up; construção de comunidades, compartilhamento de práticas. Resultados esperados: além do pacote (livro + ebook + video + site + grupo de trabalho on-line) GreenUP é atualmente uma pesquisa aplicada em andamento. Para combinar os requisitos do Design.com, apenas alguns resultados da linha de tempo são apresentados neste texto. Conclusões: a pesquisa aplicada precisa de tempo e condições favoráveis a serem testadas, antes de chegar às conclusões.

Palavras-chave: Comunidade, Projetado e Construído, Cultivo e Comida

\section{GreenUP HUB: designing and building funcional green infrastructure in Brazil}

\begin{abstract}
:
Goal Although briefly, text aims at chronologically reviewing GreenUP 5 year-long research by going back focusing on its theoretical side connected with learning - then beyond real practice. Methods: Bottom-up; community building, sharing practice. Expected results: Beyond the bundle (book+ebook+video+website+online workgroup) GreenUP is presently an ongoing applied research. To match Design.com requirements, only some timeline results are presented within this text. Conclussions: applied research needs time and favourable conditions to be tested, before heading to conclusions.
\end{abstract}

Keywords: Community, Design \& Build, Farming and Feeding 


\section{Introduction}

Having been invited by director Zoy Anastassakis, I had the pleasure to chair a brief GreenUP workshop at Esdi-UERJ in December 2016. An early outcome, the project has been presented and discussed at ENTREMEIOSImaginação coletiva e vida comum seminar which took place on December 9 at CCD-Centro Carioca de Design - a Brazilian partnership/branch office linked with Columbia University in New York.

Several months - plus several news - after that kind of experience, I'm glad to keep the present $2^{\circ}$ Seminario Design.com Articulações, Extenções e Conexões as an opportunity to go back thinking about theory and learning, to better highlight the GreenUP project and the "Articulações, Extenções e Conexões" it took since it started in 2012.

\section{Articulações: background research highlights}

Despite "Urban Green" is a trending issue among planners and architects since a while, contemporary settlements - in both cases: existing or even to be planned - hardly got anything else to offer than derelict fragments of "Third Landscape" (as French scholar Gilles Clemént uses to label them) for people to gather together, not even to share time, to farm neither. This has been reasonably the main issue for us to initiate at the Department of Architecture, University of Florence (Italy) "GreenUP - a Smart City" background research produced by CrossingLab.com think-tank.

Like any standard research, we begun to analyse critical issues after current state-of-the-art - including specific technical matters ranging hugely from green mapping and big datas, to the hydroponic tale, indeed a popular green flagship as well an emerging swindle due to its zero nutrition values etc. By the way, we have also been caring about neglected architectural practice as social design - currently forgotten due to the archi-star \& real estate allied offer for selfish style buildings, no way facing urban real issues in terms of environmental resources etc.

Skipping research hyper-specialism - often leading to both peculiar and irrelevant discoveries - has been relatively easy, eventually thanks to the rich and diverse background shared by the nearly one hundred researchers involved. Undoubtedly, this amazing crew of students, architects, botanists, engineers, agriculture experts, urban planners etc. all collaborating towards a cross-disciplinary perspective during the past five years, has been crucial for GreenUP holistic vision to be achieved. 
To reach briefly the point, GreenUP may be presently described as a sustainable, a vertical and an affordable green infrastructure designed through a highly flexible system, to deal with global issues as food security for community sharing, heat-island effect decreasing etc. A bottom-up tool, it also aims at enhancing environmental qualities such as livability - for local communities to learn growing crops, fruits and vegetables; or, eventually, thanks to special plants, it may help reducing air pollution while increasing Co2 balance within urban and metropolitan settlements. GreenUP - whose the acronym stands for Green, Recycle, Energy, Environment - may connect existing buildings to new ones by providing public spaces, like traffic-safe pathways for people to walk in etc. It may also enter semi-public scale - to help turning flat roofs into community gardens - or eventually may help surface gain for faç ades or existing balconies to be transformed into private micro-gardens. Both from a sociological and anthropological point of view, applied GreenUP also significantly helps intercultural dialogue to happen - as food caring for community feeding purpose regularly does.

By choice, GreenUP research has been entirely conceived as an interactive cross-media tool, even more structurally than other previously accomplished work of us. Previous work of us, as 03d-Da zero a tre dimensioni/From Zero To Three Dimensions (Piraz Pirazzoli, Collotti 2007) which consisted of a printed book plus its platform (at present available online at www.GPspace.org/03d), plus its kind of follow up book "1.2.3. Architettura - Manuale per i laboratori di progettazione del triennio" (Collotti, Piraz Pirazzoli, Volpe 2009) have been used as methodology references. Under this light, GreenUP is somehow close to Site Specific Museums research we chaired, which included a printed book (Piraz Pirazzoli 2011) plus an extended website acronym www.sismus.org to share online videos, blog and media contents.

Finally, GreenUP cross-media project got its own bundle including:

1. printed book (Allemandi International, Turin-London-New York 2013)

2. augmented ebook with links;

3. side-video by movie director Filippo Macelloni, with original drawings by artist Agnese Matteini: https://vimeo.com/87993255

4. website www.CrossingLab.com designed to offer a significant preview.

5. online workgroups, actually one each case-study/project, in order to share materials, files and contents about the ongoing specific work. 
This was planned to be also a way to contribute to the actual discussion - rather a debate - around MOOC-type e-learning in Architecture, then particularly in Architectural Design.

All of this meant, to us, thinking about something ready to be shared globally, then to be implemented case-by-case jointly with colleagues and professionals in order to test the outcomes. Such a somehow basic opensource setting is also the way for us to stress the contemporary challenge between the "Global" - in this case intrinsically belonging to the research framework, as displayed via the online platform - and the "Site-specific" (a concept we have been exploring enough, before finally adopting this as more relevant than "Local"). Reasonably, we may assume "think global/act sitespecific" as the project target - not by chance CrossingLab think-tank acronym stands in fact for "Crossing Research On Site Specific, Innovation, Globalisation”. Finally, under the same Global/Site-specific issue, the choice we did since the beginning at CrossingLab is to work in English, as a regular international standard; so that every step (book + ebook, video, workshops and seminars) has been processed and achieved in English, even to somehow contribute cutting short hyper-local matters.

Of course we are conscious about the problems such a choice towards the Global language over the planet could open up, but we started the job in Florence, a relevant education and research hub, due to 35 international Universities settled or represented in town. Over there, GreenUP has been first tested within iCad International Course on Architectural Design I had the honor to serve as the coordinator for. Being iCad the course for students coming from all over the world, then entirely taught in English, its teaching/learning tools cannot be otherwise, if not in English language. Intriguingly enough, then quite unexpectedly even to myself, the present working phase in Brasil is happening in Brazilian Portuguese: is this because of a popping-up site-specificity?

\section{Conexões: Networking after Theory and Practice}

Whenever networking is important for any research, for GreenUP it is vital - having been conceived for this kind of worldwide challenge. Thanks to its sharing knowledge intrinsic design, "GreenUP - a Smart City" has been developed under several site-specific cases jointly with partners institutions in Europe and abroad. To better highlight this point under its theoretical side - actually the matter for this Design.com seminar to be issued - it is reasonable to skip practical matters, in order to reflect first on the "Conceptual Network"., it is worth mentioning GreenUP first applied 
research implemented in collaboration with E.N.S.A.M.-Ecole Nationale Superieure d'Architecture Montpellier (France), where I served as a Visiting professor for the second time in 2012. Thanks to the online research setting, experimental case-studies have been developed at iCadInternational Course on Architectural Design, University of Florence. Finally, an ongoing but significant preview has been presented and widely discussed at Governing the Metropolis International Conference, SciencesPo Paris 2012. For this having been formally the first opportunity to share the research framework with reputed colleagues, we collected great feedbacks as for instance the one from Amitabh Kundu, Professor of Economics at Jawaharlal Nehru University, New Delhi, who stated "We need not just better modelling and more rigorous econometric analysis of the socioeconomic data but also visionaries who can link up history with future perspectives of city development." Actually, although it took a while to keep it literally, we successfully developed a model to simulate and check datas before/after an existing building has been retrofitted with GreenUP layer.

Briefly later, in 2013 the School of Architecture at the Munich University of Applied Sciences (Germany) appointed me as a Visiting Professor, then providing a significant opportunity to directly share GreenUP over there. Also in Munich, private Q\&A art/architecture platform produced an excellent workshop, then a brilliant GreenUP project upgrade has been achieved; although, unfortunately, a public-private granted incubator called SCE-Strascheg Center for Entrepreneurship failed on its side-traineeship mission, despite the two grants we provided from Italy - then the work remained unfinished, for us being forced to learn that research sometime needs even to fail. "Ever tried. Ever failed. No matter. Try again. Fail again. Fail better", as Samuel Beckett noted in his Worstward Ho (1983) novel.

Later on, in 2014, GreenUP has been awarded the "Urban Connectors" TED x Conference: http://www.tedxhamburg.de/greenup-asmart-city-giacomo-pirazzoli-at-tedxhamburg-urban-connectors an event which - despite a certain academic disdain - amazingly contributed for GreenUP workshops and seminars to take place abroad.

For instance - beside the many calls and invitations received to implement GreenUP here and there, which are a part of the regular timewasting networking job - in the USA, renowned Bronx activist Majora Carter and renowned Greening the Ghetto project leader endorsed the work. Worth to say that her own statement "GreenUP shows what can happen when one views the challenge of urban areas as opportunities" paved the way for collaborations and further practical steps; right after the same US 
tour - which included also Rural Studio's Design \& Build practice in Alabama etc. - other GreenUP development opportunities took place at AAPI_Australian Asian Pacific Institute (Curtin University, PerthAustralia), then - with a special focus on preservation - at China Academy of Art (Hangzhou-China); this beside the intriguing Workshop as a Design Tool seminar at the Polytechnic University in Turin-Italy, actually a nice opportunity to start thinking back in terms of theory.

Coming to Brazil, GreenUP has been first invited at "Semana do Clima" European Commission EU/Brazil International Joint Conference in Rio de Janeiro, November 2015: https://vimeo.com/205563169

A little break after the "Semana do Clima" allowed a significant feed-back self-evaluation to be undertaken: having been GreenUPing enough around the world while testing its kind of MOOC e-learning environment, we finally realize that - particularly for Architectural design live teaching strategy is crucial, while on-line teaching interaction helps a lot. In other words, live and on-line learning practices need to be strongly integrated. Back at CrossingLab in Florence, we agreed on a new printed book+ebook to be edited to collect the huge amount of work developed and achieved.

\section{Extenções: the GreenUP HUB - Healthy Food and Clean Air}

After those practice-oriented opportunities, two follow-up seminars took place in 2016 at Esdi-Escola Superior Desenho Industrial in Rio de Janeiro actually the above mentioned work discussed at ENTREMEIOS-Imaginaçao coletiva e vida comum - as well as another seminar at FAU-Mackenzie in São Paulo. This latter came out as the opportunity for a CAPES grant to be issued in 2017, in order to implement a couple of socially relevant cases previously studied by Mackenzie colleagues in São Paulo thanks to a strong connection with local communities.

Before attaching the actually ongoing CAPES program "GreenUP: cidade como paisagem comestivel" - a GreenUP HUB - Healthy Food and Clean Air sub-program also designed as a hub to somehow connect FAU and CCBS-Mackenzie with UERJ-Esdi through a consistent theory \& learning effort to include Tópico especial, Extensão, Design \& Build, plus Prototyping I am proud to recall the practical side of this work.

Beyond any theoretical matter, GreenUP can in fact be reasonably understood when recalling above mentioned highly-flexible green infrastructure, rather a green backbone (aka Network) to properly connect or wrap around existing buildings (aka Hardware) and temporary/removable structures (aka 
Software). This even allows Hi-Tech components to be added in some cases, while basic/affordable releases have been also developed for extreme environments as shanty town, favelas etc.

At least, GreenUP is a real systemic design tool to face and solve substantial United Nations matters about growing metropolitan settlements, food scarcity due to agricultural intensive chemical use, substantial lack of biodiversity etc. Transforming contemporary metropolis into paisagem comestivel [edible landscape] for people to enjoy then to better live in requires an appropriate dose of theory jointly with the consistent design job we already did.

Now ready for a brilliant alliance merging entrepreneurial issues with sharp social practice. 


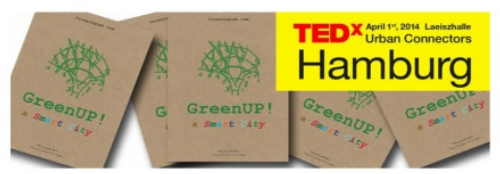

\section{GreenUP: cidade como paisagem comestível}

\section{Topico Especial/Extensão}

GreenUP - a Smart City é a pesquisa coordenada pelo prof.Giacomo Pirazzoli (Università di Firenze, Italia) produzida pelo think-tank crossinglab.com com parcerias em Europa, China, Austrália. o projeto cross-medial inclui:

1. livro "GreenUP - a Smart City" editado pela Allemandi International, Turin-London-New York 2013

2. ebook com links;

3. video https://vimeo.com/87993255

4. website preview www.CrossingLab.com

5. online workgroup tipo MOOC

Um trabalho holístico que envolveu mais de 100 pessoas nos últimos cinco anos com pensamento global e ação local, GreenUP é um sistema de projeto para espaços urbanos a serem requalificados por meio de atitudes sustentáveis. Palavras chaves: jardins e hortas verticais, alimentação saudável, PANCs, comunidade, mudança do clima \& ilha do calor. Mais informações: TEDxConference

http: //www.tedxhamburg.de/greenup-a-smart-city-giacomo-pirazzoli-at-tedxhamburg-urban-connectors GreenUP: cidade como paisagem comestível é parte do programa CAPES 2017 GreenUP HUB - Healthy Food and Clean Air aplicado no Brasil a convite dos grupos de pesquisa LPP/Laboratorio de Projetos e Politicas Públicas e Q.URB-Questões Urbanas, ambos sediados na FAU-Mackenzie São Paulo, com curadoria do Prof.Giacomo Pirazzoli e colaboração da UERJ-Escola Superior Desenho Industrial.

Focada na conceição da infraestrutura para a horta e comida comunitária GreenUP com prospetiva metodologica Design \& Build (Projeto e construção) a pesquisa é compartilhada entre estudantes, professores FAU+CCBS e membros da comunidade. No âmbito desse convênio já está sendo aplicada no Rio de Janeiro. Além da propria pesquisa academica, em São Paulo tem estudos de caso GreenUP no Jardim Piratininga (bairro da Penha) integrando ações do Plano do Bairro em elaboração desde 2015 pelo grupo Q.URBQuestões Urbanas e na favela do Moinho pelo grupo LPP-Laboratorio de Projetos e Politicas Públicas, ainda em colaboração com outras entidades e parceiros da sociedade civil.

Comitê Cientifico:

Giacomo Pirazzoli (coord.), Ana Carolina A. Colucci Paternez; Ana Paula Calvo; Andrea Romero de Almeida; Camila de Meirelles Landi; Eunice Helena S. Abascal; Leandro $T$. Azevedo Vieira; Magno Botelho Castelo Branco; Maria Augusta Justi Pisani; Marilia Malzoni Marchi; Mauro Claro; Pérola Felipette Brocaneli; Valter Caldana.

CAPES MC:Bis




\section{GreenUP: cidade como paisagem comestível \\ Atividades em São Paulo \\ Campus Mackenzie Higienópolis e Jardim Piratininga}

1. Filmes com discussão, prédio 9/sala 306, 12.10-13.45h Capacitação horizontal para estudantes de graduação, pós, mestrado, doutorado. 4 aulas presenciais+2 com implementação on line (tipo MOOC). Estudantes FAU: Tópico Especial; estudantes CCBS: Extensão

25.09, segunda. ATIVISMO URBANO \& COMUNIDADE com Baixo Ribeiro (www.choquecultural.com.br), Elena Olaszek, Marcos L.Rosa (11a Bienal de Arquitetura, São Paulo), Valter Caldana - coord. Giacomo Pirazzoli

27.09, quarta. CULTIVo \& COMIDA com Ana Carolina A.C. Paternez, Camila De Meirelles Landi, Marilia Malzoni Marchi - coord. Giacomo Pirazzoli

02.10, segunda. GreenUP: A PESQUISA INTERNACIONAL por Giacomo Pirazzoli 04.10, quarta. VISITA GUIADA AO JARDIM PIRATININGA por Ana Paula calvo e Mauro Claro com Giacomo Pirazzoli - h.12.10 saida do saguão do predio 9

16.10, segunda. CIDADE \& CULTIVo com Pérola Felipette Brocaneli, Leandro T. Azevedo Vieira, Magno Botelho Castelo Branco - coord. Giacomo Pirazzoli

2. Workshop FAU+CCBS (extensão) prédio 9/sala 306

Desenvolvimento do projeto GreenUP-estudo de caso Jardim Piratininga, com olhar metodologico Design \& Build e implementação comunidaria online tipo Mooc.

18.10, quarta.

Semana Viver Metrópole Horta vertical GreenUP para comida saudavel. $18-22 \mathrm{~h}$. Horta vertical GreenuP para comida
estudo de caso Jardim Piratininga

19.10, quinta.

Semana Viver Metrópole Horta vertical GreenUP para comida saudavel: $18-22 \mathrm{~h}$. estudo de caso Jardim Piratininga

20.10, sesta.

Semana Viver Metrópole Horta vertical GreenUP para comida saudavel: $18-22 \mathrm{~h}$. apresentação do projeto durante o cocktail de confraternização com lideranças do Jardim Piratininga - coord. Marilia Malzoni

21.10 , sabado. (parceria FAU+CCBS)

ao JARDIM PIRATININGA Horta vertical GreenUP para comida saudavel: $10-18 \mathrm{~h}$. Estudantes \& moradores discutindo o projeto

$28.10 ; 11.11 ; 25.11 ; 9.12$ - sábados:

Sessões colaborativas - estudantes \& moradores no JARDIM PIRATININGA.

apoio:

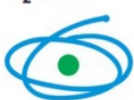

CAPES

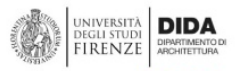

ESDI

\AAOPAULO

realização:
q.URB
LPP

(M) ${ }_{\text {centrode }}^{\mathrm{CCBS}}$

$\mathbf{1 0 0}$ 


\section{Como citar}

PIRAZZOLI, Giacomo. GreenUp HUB: projetando e construindo infraestruturas verdes funcionais no Brasil. Arcos Design. Rio de Janeiro: PPD ESDI - UERJ. Edição Especial Seminário Design.Com. pp. 20-31. Disponível em:

[http://www.e-publicacoes.uerj.br/index.php/arcosdesign]

DOI 10.12957/arcosdesign.2017.30938

\section{(c) (1) (8)(2)}

A Revista Arcos Design está licenciada sob uma licença Creative Commons Atribuição - Não Comercial - Compartilha Igual 3.0 Não Adaptada. 